\title{
ULTRASOUND ASSESSMENT OF RIGHT INTERNAL JUGULAR VEIN DIMENSIONS FOLLOWING PASSIVE LEGS ELEVATION VERSUS HEPATIC COMPRESSION
}

\author{
Jasim M Salman ${ }^{\circledR}$, Mohammed Jamal Jasim \& Salam N Asfar ${ }^{\#}$ \\ ${ }^{\circledR}$ MB,ChB, DA, FICMS Anesth., Assist. Prof. \& Consultant Anesthesiologist, College of Medicine, \\ University of Basrah. *MB,ChB, FICMS Anesth. Candidate, Alsadr Teaching Hospital. \#MB,ChB, MSc \\ Anesth., Professor of Anesthesiology, College of Medicine, University of Basrah, Basrah, IRAQ.
}

\begin{abstract}
Central venous catheterization has an essential role in the management of patients who are critically ill, and patients who have special operative interventions. In general, the bigger the vein cross sectional area and diameter the easier the catheterization will be. There are different maneuvers to increase internal jugular vein caliber. These include; passive legs elevation, hepatic or abdominal compression, Trendelenburg position, Valsalva maneuver, and positive end-expiratory pressure.

The objective of the study is to evaluate the effect of passive legs elevation and hepatic compression on the diameter and the cross-sectional area of the right internal jugular vein.

This prospective study included 80 adult patients ASA class I and II. Patients who had any contraindication to the passive legs elevation or hepatic compression, or those with disruption of the local neck anatomy; were excluded from the study. Patients were evaluated for their right internal jugular vein cross-sectional area and diameter by the use of linear high frequency twodimensional ultrasound. Each patient has three stages of measurement; supine, Passive legs elevation at (30o-45o) for one minute, and hepatic compression.

Of the 80 patients, $70 \%$ were males, the age range was (19-55 years) with a mean of $(37.75 \pm 12.16)$ years, and the majority were overweight. The maximum diameter was achieved during hepatic compression with a stepwise statistically significant increase of about $(0.44 \pm 0.27$ $\mathrm{cm})$ from the baseline in supine position, when compared to only $(0.26 \pm 0.21 \mathrm{~cm})$ during passive legs elevation. The cross-sectional area is significantly and maximally increased from the baseline of $(0.93 \pm 0.59 \mathrm{~cm} 2)$, during hepatic compression. The increase in the diameter and the cross sectional area was more significant in males irrespective to age and weight.

In conclusion, Hepatic compression is significantly superior to the passive legs elevation in achieving more right internal jugular vein diameter and cross-sectional area.

Key words: Internal jugular vein, supine position, passive legs elevation, hepatic compression, maximum diameter and cross sectional area.
\end{abstract}

\section{Introduction}

Utilizing the internal jugular veins catheterization has become a mandatory part of clinical management in a variety of clinical circumstances ${ }^{1}$ and it is an integral part in the management of critically ill patients ${ }^{2}$. The anatomical landmark-guided ultrasound technique of the IJV significantly increases the success rate, decreases procedure access time, and reduces complication rate ${ }^{1,3}$. Technically, the IJV cannulation is more difficult in infants and children than in adults ${ }^{4}$ due to the smaller veins size and possible variable anatomical relations ${ }^{5}$. The variable position of the IJV and its proximity to the carotid artery may lead to this difficulty ${ }^{4,5}$.

The anatomical variations in IJV position and unreliability of the external landmarks may be contributed for cannulation complications and failure ${ }^{2}$. The external landmarks may not correlate precisely to the location of the vessel ${ }^{1,6}$. The possible complications are; puncture of the carotid artery, neck or mediastinal 
hematoma, brachial plexus injury, pneumothorax, and injury to the stellate ganglion, phrenic, or recurrent laryngeal nerve ${ }^{1-3}$.

The right IJV is more preferred over the left IJV because of; its straight course into the superior vena cava, and also the pleural dome is lower on the right side. Cannulation attempts of the left IJV may have the risk for thoracic duct injury ${ }^{7,8}$. Lobato et al. found that in one-third of adults, the left IJV is significantly smaller compared with the right IJV and, that may increase the level of difficulty for cannulation ${ }^{9}$.

There is a significant relationship between the increase in the diameter of the IJV and the success rate at the first attempt of catheterization, therefore, the bigger the diameter of the IJV the easier the catheterization will be ${ }^{10}$.

Large veins have a greater distensibility and compliance within the physiological pressure range compared to arteries. This will help to keep venous pressure within the normal range ${ }^{11,12}$.

The biomechanical properties of veins depend on age, gender, body mass, and body position which is affected by gravity. In the supine position, the intraluminal pressure of IJV steeply increases, and the distensibility of the venous wall decreases this will form most of the cerebral venous drainage in the majority of healthy subjects ${ }^{11,12}$.

Changing to a sitting or upright position, IJV distensibility increases as the transmural pressure approaches $0 \mathrm{mmHg}$; consequently, IJV collapses and blood flow resistance raises. In these positions, a larger part of the cerebral venous drainage is ensured by the vertebral venous system ${ }^{11}$.

Even with the ultrasound guide, cannulation of the IJV can be challenging in; hypovolemic patients, those with an unstable cervical spine, a short thick neck, increased intracranial pressure, endstage renal disease, previous IJV cannulations, and/or intraluminal obstruction $^{13}$. Because IJV cannulation would be easier on a large IJV, it is necessary to look for a maneuver to increase the cross-sectional area (CSA) of IJV in critically ill patients ${ }^{14}$.

The CSA of the right IJV increases with the use of the; Trendelenburg (T) position, hepatic compression, Valsalva maneuver, passive leg elevation (PLE), \& positive end-expiratory pressure ${ }^{4,5,15-17}$, thus improving the cannulation success rate. These procedures reduce the time of cannulation and avoids the complications associated with multiple attempts, the incidence of inadvertent arterial puncture and the number of attempts required before successful cannulation ${ }^{3,13}$.

The $\mathrm{T}$ position and hepatic compression are used during IJV cannulation in infants and children [4]. The combination of these maneuvers offer a maximal mean increase in the CSA of the right IJV in patients who needed central venous cannulation $^{4,5,15,18,19}$, yet, the Valsalva maneuver or abdominal compression may be cumbersome and create discomfort to patients who are awake ${ }^{15}$.

The PLE redistributes more blood from the lower limbs into the central veins and can be performed relatively easily thus is commonly used for hypovolemic shock ${ }^{15}$. The PLE is an easier and practical maneuver to enhance the IJV congestion $^{14,15}$, it is as effective as $\mathrm{T}$ maneuver ${ }^{15}$, and could be used as an alternative to increase the IJV dimensions where the $\mathrm{T}$ position cannot be used, or cause a harmful effect ${ }^{10,15}$, especially in mechanically ventilated patients ${ }^{18}$. In infants or small children, PLE can be performed easily so avoids the increase of intracranial pressure and does not require a table tilt for head-down position ${ }^{5}$.

Hepatic compression increases the CSA of the right IJV significantly in supine patients and can be used when the $(\mathrm{T})$ position is not advisable or possible. Performing hepatic compression with patients in the $T$ position may facilitate cannulation, possibly by making the vein 
less collapsible due to increased intravascular pressure ${ }^{17}$. Bellazzini et al. found that hepatic compression alone would not lead to a statistically significant increase in IJV CSA in comparison with Valsalva maneuver, they also concluded that it would be better to use a combination of these two methods ${ }^{20}$.

The aim of this study is to evaluate hepatic compression and passive leg raising in increasing the diameter and the cross-sectional area of the right internal jugular vein in Al-Sadr Teaching Hospital in Basrah, Southern of Iraq.

\section{Patients and Methods}

This cross sectional study was done in the outpatient clinic in Al-Sadr Teaching Hospital from May to October 2019. Ethical approval of the Iraqi Council of Anesthesia and Critical Care was obtained.

The inclusion criteria included: Patients who have American association of Anesthesia class I and II, awake nonsurgical spontaneously breathing patients, and age groups ranged from 19 to 55 years.

The exclusion criteriaincluded: Patients who refused to participate in the study, irritable patient patients with history of neck surgery or trauma, patients with history of previous right IJV cannulation, patients with goiter or any neck swelling, pregnancy, hemodynamically unstable patients, patients with abdominal swelling or distention caused by masses, hepatomegaly, or ascites, and when the maneuver interferes with the original condition, e.g. leg elevation in patients with lower extremity fracture or deep vein thrombosis or hepatic compression in patients with abdominal surgery, trauma, pain, and tenderness.

The final involved patients who fulfill the inclusion criteria were 80 patients, 56 males and 24 females. The maximum diameter and CSA of the right IJV were evaluated in using these two maneuvers after obtaining a written consent from each patient.

Study Protocol

A GE Logiq P5 ultrasound device with two-dimensional $10 \mathrm{MHz}$ linear probe was used to obtain a real-time ultrasound images. In order to eliminate the respiratory effect, the investigator selected the image showing the largest diameter and CSA which were measured by planimetry. The circumference of the right IJV was delineated using the electronic marker. The same investigator obtained all images in order to achieve consistency in measurements. The probe was applied with the lightest possible pressure and held perpendicular to the skin of the subjects in horizontal supine position. All images of the right IJV were obtained at the level of the cricoid cartilage, with the patient laying down and head rotated $15^{\circ}-30^{\circ}$ to the left side.

Each patient underwent three stages of measurement; in each stage we measure the maximum diameter and the CSA of right IJV.

Stage I: First measurement was done in a supine position without applying any maneuver (control).

Stage II: Passive legs elevation was done at $30^{\circ}-45^{\circ}$ and then the second measurement was taken after one minute. Stage III: The patients returned back to supine position for at least one minute, then hepatic compression was done by hand for one minute and after that, a third measurement was obtained.

All the other demographic characteristics were evaluated for each patient including; Age, gender, body mass index (BMI), and vital signs.

The measurements of blood pressure included systolic, diastolic blood pressure (SBP and DBP respectively), and mean arterial pressure (MAP).

Statistical Evaluation: Statistical Packages for Social Sciences Software (IBM-SPSS-23) was used. The demonstration of different variables in the study was done by using mean \pm standard 
deviation (SD). The paired sample $t$ test was used to evaluate the maximum diameter and CSA. A P-value less than 0.05 was considered as significant.

\section{Results}

Table I demonstrates the different demographic characteristics of all the involved 80 patients. The mean age was
$37.75 \pm 12.16$ years, with an age range of $19-55$ years. There were $50 \%$ of the patients below the age of 40 years. Males constituted $70 \%$ of the cohort. The mean body mass index (BMI) of the patients was in the overweight category. The preliminary readings of the means of systolic blood pressure, diastolic blood pressure, and mean arterial pressure were within normal range.

Table I: General characteristics and the baseline measurements of the enrolled patients $(\mathbf{N}=\mathbf{8 0})$.

\begin{tabular}{|l|l|l|}
\hline Variable & Mean \pm Standard deviation & $\mathrm{N}(\%)$ \\
\hline Age (years) range $(19-55)$ & $37.75 \pm 12.16$ & \\
\hline Age $>40$ years & & $40(50 \%)$ \\
\hline Male gender & & $56(70 \%)$ \\
\hline Body mass index $(\mathrm{kg} / \mathrm{m} 2)$ & $26.53 \pm 2.21$ & \\
\hline Body mass index $>25(\mathrm{~kg} / \mathrm{m} 2)$ & & $28(35 \%)$ \\
\hline Systolic blood pressure $(\mathrm{mmHg})$ & $121.75 \pm 8.89$ & \\
\hline Diastolic bloodpressure $(\mathrm{mmHg})$ & $77 \pm 7.18$ & \\
\hline Mean arterial pressure $(\mathrm{mmHg})$ & $91.91 \pm 6.86$ & \\
\hline
\end{tabular}

The maximum right IJV diameter was achieved during hepatic compression with a stepwise increase from the baseline in supine position $(1.32 \pm 0.43 \mathrm{~cm})$ to be $1.77 \pm$ $0.39 \mathrm{~cm}$, the amount of increase was about $0.44 \pm 0.27 \mathrm{~cm}$, as shown in Table II-A.

Table II (A): Comparison for the right internal jugular vein maximum diameter between supine position versus hepatic compression in different patient groups.

\begin{tabular}{|c|c|c|c|c|}
\hline \multirow[b]{2}{*}{ Variables } & \multicolumn{3}{|c|}{ Mean \pm SD for IJV maximum diameter $(\mathrm{cm})$} & \multirow[b]{2}{*}{$\begin{array}{l}\text { Paired } \\
\text { t test } \\
\text { P value* }\end{array}$} \\
\hline & Control & $\begin{array}{l}\text { Hepatic } \\
\text { compression }\end{array}$ & $\begin{array}{l}\text { Difference } \\
\text { Hepatic compress. } \\
\text { to Control }\end{array}$ & \\
\hline Overall & $1.32 \pm 0.43$ & $1.77 \pm 0.39$ & $0.44 \pm 0.27$ & $<0.001$ \\
\hline $\begin{array}{l}\text { Age } \geq 40 \text { years } \\
\text { Age }<40 \text { years }\end{array}$ & $\begin{array}{l}1.45 \pm 0.45 \\
1.19 \pm 0.43\end{array}$ & $\begin{array}{l}1.90 \pm 0.33 \\
1.63 \pm 0.41\end{array}$ & $\begin{array}{l}0.45 \pm 0.25 \\
0.43 \pm 0.29\end{array}$ & $\begin{array}{l}<0.001 \\
<0.001\end{array}$ \\
\hline P value** & & & 0.807 & \\
\hline $\begin{array}{l}\text { Men } \\
\text { Women }\end{array}$ & $\begin{array}{l}1.39 \pm 0.36 \\
1.17 \pm 0.54\end{array}$ & $\begin{array}{l}1.88 \pm 0.32 \\
1.52 \pm 0.45\end{array}$ & $\begin{array}{l}0.48 \pm 0.28 \\
0.34 \pm 0.22\end{array}$ & $\begin{array}{l}<0.001 \\
<0.001\end{array}$ \\
\hline $\mathrm{P}$ value** & & & 0.036 & \\
\hline $\begin{array}{l}\text { BMI } \quad \geq 25 \\
(\mathrm{~kg} / \mathrm{m} 2)\end{array}$ & $1.42 \pm 0.48$ & $1.86 \pm 0.38$ & $0.45 \pm 0.22$ & $<0.001$ \\
\hline $\begin{array}{l}\text { BMI } \quad<25 \\
(\mathrm{~kg} / \mathrm{m} 2)\end{array}$ & $1.15 \pm 0.24$ & $1.60 \pm 0.37$ & $0.44 \pm 0.29$ & $<0.001$ \\
\hline $\mathrm{P}$ value** & & & 0.791 & \\
\hline
\end{tabular}


There was only $0.26 \pm 0.21 \mathrm{~cm}$ increase in the right IJV maximum diameter from the supine position to be $1.59 \pm 0.44 \mathrm{~cm}$ during passive legs elevation, as demonstrated in Table II B.

Table II (B): Comparison for the right internal jugular vein maximum diameter between supine position versus passive legs elevation in different patient groups.

\begin{tabular}{|c|c|c|c|c|}
\hline \multirow[b]{2}{*}{ Variables } & \multicolumn{3}{|c|}{ Mean \pm SD for IJV maximum diameter $(\mathrm{cm})$} & \multirow{2}{*}{$\begin{array}{l}\text { Paired } \\
\text { t test } \\
\text { pvalue* }\end{array}$} \\
\hline & Control & $\begin{array}{ll}\begin{array}{l}\text { Passive } \\
\text { elevation }\end{array} & \text { legs } \\
\end{array}$ & $\begin{array}{l}\text { Difference Passive legs } \\
\text { elevation to Supine }\end{array}$ & \\
\hline Overall & $1.32 \pm 0.43$ & $1.59 \pm 0.44$ & $0.26 \pm 0.21$ & $<0.001$ \\
\hline $\begin{array}{l}\text { Age } \geq 40 \\
\text { Age }<40\end{array}$ & $\begin{array}{l}1.45 \pm 0.40 \\
1.19 \pm 0.43\end{array}$ & $\begin{array}{l}1.70 \pm 0.45 \\
1.47 \pm 0.40\end{array}$ & $\begin{array}{l}0.27 \pm 0.25 \\
025 \pm 0.16\end{array}$ & $\begin{array}{l}<0.001 \\
<0.001\end{array}$ \\
\hline $\mathrm{P}$ value** & & & 0.581 & \\
\hline $\begin{array}{l}\text { Men } \\
\text { Women }\end{array}$ & $\begin{array}{l}1.39 \pm 0.36 \\
1.17 \pm 0.54\end{array}$ & $\begin{array}{l}1.70 \pm 0.38 \\
1.31 \pm 0.44\end{array}$ & $\begin{array}{l}0.31 \pm 0.21 \\
0.14 \pm 0.17\end{array}$ & $\begin{array}{l}<0.001 \\
<0.001\end{array}$ \\
\hline $\mathrm{P}$ value** & & & $<0.001$ & \\
\hline $\begin{array}{l}\mathrm{BMI} \\
(\mathrm{kg} / \mathrm{m} 2)\end{array}$ & $1.42 \pm 0.48$ & $1.65 \pm 0.47$ & $0.32 \pm 0.22$ & $<0.001$ \\
\hline $\begin{array}{ll}\mathrm{BMI} & <25 \\
(\mathrm{~kg} / \mathrm{m} 2) & \end{array}$ & $1.15 \pm 0.24$ & $1.47 \pm 0.34$ & $0.23 \pm 0.20$ & $<0.001$ \\
\hline $\mathrm{P}$ value** & & & 0.079 & \\
\hline
\end{tabular}

Overall, the maximal right IJV diameter was achieved with statistical significant relationship using the hepatic compression in comparison to control, especially in males. Age and BMI show statistically insignificant relationship.

Regarding CSA of the right IJV in the control group, it was $1.34 \pm 0.82 \mathrm{~cm}^{2}$ which increased by $0.38 \pm 0.33 \mathrm{~cm}^{2}$ when passive legs elevation is used to be $1.72 \pm 0.92 \mathrm{~cm}^{2}$ as shown in Table III A, but when the hepatic compression was applied it had increase about $\left(0.93 \pm 0.59 \mathrm{~cm}^{2}\right)$ from the baseline supine position to be $2.27 \pm 1.15 \mathrm{~cm}^{2}$, Table III (B).

Table III (A): Comparison of the right internal jugular cross-sectional area between control group versus passive legs elevation in different patient groups.

\begin{tabular}{|c|c|c|c|c|}
\hline \multirow[b]{2}{*}{ Variables } & \multicolumn{3}{|c|}{ Mean \pm SD for IJV CSA $\left(\mathrm{cm}^{2}\right)$} & \multirow[b]{2}{*}{$\begin{array}{l}\text { Paired } \\
\text { t test } \\
\text { P value* }\end{array}$} \\
\hline & Control & $\begin{array}{l}\text { Passive } \\
\text { elevation }\end{array}$ & $\begin{array}{lr}\text { Difference } & \\
\text { Passive } & \text { legs } \\
\text { elevation } & \text { to } \\
\text { control } & \\
\end{array}$ & \\
\hline Overall & $1.34 \pm 0.82$ & $1.72 \pm 0.92$ & $0.38 \pm 0.33$ & $<0.001$ \\
\hline $\begin{array}{l}\text { Age } \geq 40 \text { years } \\
\text { Age }<40 \text { years }\end{array}$ & $\begin{array}{l}1.66 \pm 0.87 \\
1.01 \pm 0.64\end{array}$ & $\begin{array}{l}2.06 \pm 1.05 \\
1.38 \pm 0.63\end{array}$ & $\begin{array}{l}0.40 \pm 0.43 \\
0.36 \pm 0.21\end{array}$ & $\begin{array}{l}<0.001 \\
<0.001\end{array}$ \\
\hline $\mathrm{P}$ value** & & & 0.584 & \\
\hline $\begin{array}{l}\text { Men } \\
\text { Women }\end{array}$ & $\begin{array}{l}1.48 \pm 0.84 \\
1.01 \pm 0.68\end{array}$ & $\begin{array}{l}1.93 \pm 0.95 \\
1.23 \pm 0.65\end{array}$ & $\begin{array}{l}0.45 \pm 0.37 \\
0.22 \pm 0.15\end{array}$ & $\begin{array}{l}<0.001 \\
<0.001\end{array}$ \\
\hline $\mathrm{P}$ value** & & & $<0.001$ & \\
\hline $\begin{array}{l}\text { BMI } \geq 25\left(\mathrm{~kg} / \mathrm{m}^{2}\right) \\
\mathrm{BMI}<25\left(\mathrm{~kg} / \mathrm{m}^{2}\right)\end{array}$ & $\begin{array}{l}1.54 \pm 0.89 \\
0.96 \pm 0.52\end{array}$ & $\begin{array}{l}1.93 \pm 1.01 \\
1.33 \pm 0.57\end{array}$ & $\begin{array}{l}0.39 \pm 0.40 \\
0.37 \pm 0.18\end{array}$ & $\begin{array}{l}<0.001 \\
<0.001\end{array}$ \\
\hline $\mathrm{P}$ value** & & & 0.854 & \\
\hline
\end{tabular}


Table III (B): Comparison for the right internal jugular cross-sectional area between control versus Hepatic compression in different patient groups.

\begin{tabular}{|c|c|c|c|c|}
\hline \multirow[b]{2}{*}{ Variables } & \multicolumn{3}{|c|}{ Mean \pm SD for IJV CSA $\left(\mathrm{cm}^{2}\right)$} & \multirow[b]{2}{*}{$\begin{array}{l}\text { Paired } \\
\text { t test } \\
\text { P value* }\end{array}$} \\
\hline & Control & $\begin{array}{l}\text { Hepatic } \\
\text { compression }\end{array}$ & $\begin{array}{l}\text { Difference Hepatic } \\
\text { compression to } \\
\text { control }\end{array}$ & \\
\hline Overall & $1.34 \pm 0.82$ & $2.27 \pm 1.15$ & $0.93 \pm 0.59$ & $<0.001$ \\
\hline Age $\geq 40$ years & $1.66 \pm 0.87$ & $2.69 \pm 1.34$ & $1.03 \pm 0.67$ & $<0.001$ \\
\hline Age $<40$ years & $1.01 \pm 0.64$ & $1.85 \pm 0.74$ & $0.84 \pm 0.50$ & $<0.001$ \\
\hline $\mathrm{P}$ value** & & & 0.155 & \\
\hline Men & $1.48 \pm 0.84$ & $2.57 \pm 1.19$ & $1.08 \pm 0.63$ & $<0.001$ \\
\hline Women & $1.01 \pm 0.68$ & $1.58 \pm 0.68$ & $0.57 \pm 0.28$ & $<0.001$ \\
\hline $\mathrm{P}$ value** & & & $<0.001$ & \\
\hline $\mathrm{BMI} \geq 25(\mathrm{~kg} / \mathrm{m} 2)$ & $1.54 \pm 0.89$ & $2.53 \pm 1.26$ & $0.99 \pm 0.63$ & $<0.001$ \\
\hline $\mathrm{BMI}<25(\mathrm{~kg} / \mathrm{m} 2)$ & $0.96 \pm 0.52$ & $1.78 \pm 0.72$ & $0.82 \pm 0.52$ & $<0.001$ \\
\hline $\mathrm{P}$ value** & & & 0.171 & \\
\hline
\end{tabular}

Table IV (A) and table IV (B), additionally demonstrated that hepatic compression is significantly superior to the leg elevation in terms of both right IJV diameter and the CSA in males regardless to age and BMI.

Table IV (A): Comparison of the right internal jugular vein maximum diameter between passive legs elevation versus hepatic compression in different patient groups.

\begin{tabular}{|c|c|c|c|c|}
\hline \multirow[b]{2}{*}{ Variables } & \multicolumn{3}{|c|}{ Mean \pm SD for IJV maximum diameter $(\mathrm{cm})$} & \multirow[b]{2}{*}{$\begin{array}{l}\text { Paired } \\
\text { t test } \\
\text { P value* }\end{array}$} \\
\hline & $\begin{array}{l}\text { Passive legs } \\
\text { elevation }\end{array}$ & $\begin{array}{l}\text { Hepatic } \\
\text { compression }\end{array}$ & $\begin{array}{l}\text { Difference, Hepatic } \\
\text { compression to Passive } \\
\text { legs elevation }\end{array}$ & \\
\hline Overall & $1.59 \pm 0.44$ & $1.77 \pm 0.39$ & $0.18 \pm 0.19$ & $<0.001$ \\
\hline $\begin{array}{l}\text { Age } \geq 40 \\
\text { years }\end{array}$ & $1.70 \pm 0.40$ & $1.90 \pm 0.33$ & $0.20 \pm 0.24$ & $<0.001$ \\
\hline $\begin{array}{l}\text { Age }<40 \\
\text { years }\end{array}$ & $1.47 \pm 0.40$ & $1.63 \pm 0.41$ & $0.16 \pm 0.13$ & $<0.001$ \\
\hline $\mathrm{P}$ value** & & & 0.347 & \\
\hline Men & $1.70 \pm 0.38$ & $1.88 \pm 0.32$ & $0.17 \pm 0.21$ & $<0.001$ \\
\hline Women & $1.31 \pm 0.44$ & $1.52 \pm 0.45$ & $0.20 \pm 0.13$ & $<0.001$ \\
\hline $\mathrm{P}$ value** & & & 0.441 & \\
\hline $\begin{array}{l}\text { BMI } \geq 25 \\
(\mathrm{~kg} / \mathrm{m} 2)\end{array}$ & $1.65 \pm 0.47$ & $1.86 \pm 0.38$ & $0.20 \pm 0.23$ & $<0.001$ \\
\hline $\begin{array}{l}\text { BMI <25 } \\
(\mathrm{kg} / \mathrm{m} 2)\end{array}$ & $1.47 \pm 0.34$ & $1.60 \pm 0.37$ & $0.13 \pm 0.07$ & $<0.001$ \\
\hline $\mathrm{P}$ value** & & & 0.044 & \\
\hline
\end{tabular}


Table IV (B): Comparison of the right internal jugular cross-sectional area between Passive legs elevation versus Hepatic compression in different patient groups.

\begin{tabular}{|c|c|c|c|c|}
\hline \multirow[b]{2}{*}{ Variables } & \multicolumn{3}{|c|}{ Mean \pm SD for IJV CSA $\left(\mathrm{cm}^{2}\right)$} & \multirow[b]{2}{*}{$\begin{array}{l}\text { Paired } \\
\mathrm{t} \text { test } \\
\text { P value* }\end{array}$} \\
\hline & $\begin{array}{l}\text { Passive legs } \\
\text { elevation }\end{array}$ & $\begin{array}{l}\text { Hepatic } \\
\text { compression }\end{array}$ & $\begin{array}{l}\text { Difference } \begin{array}{r}\text { Hepatic } \\
\text { compression } \\
\text { elevation }\end{array} \\
\text { to passive legs }\end{array}$ & \\
\hline Overall & $1.72 \pm 0.92$ & $2.27 \pm 1.15$ & $0.55 \pm 0.47$ & $<0.001$ \\
\hline $\begin{array}{l}\text { Age } \geq 40 \\
\text { years }\end{array}$ & $2.06 \pm 1.05$ & $2.69 \pm 1.34$ & $0.62 \pm 0.53$ & $<0.001$ \\
\hline $\begin{array}{l}\text { Age }<40 \\
\text { years }\end{array}$ & $1.38 \pm 0.63$ & $1.85 \pm 0.74$ & $0.47 \pm 0.40$ & $<0.001$ \\
\hline $\mathrm{P}$ value** & & & 0.160 & \\
\hline $\begin{array}{l}\text { Men } \\
\text { Women }\end{array}$ & $\begin{array}{l}1.93 \pm 0.95 \\
123+0.65\end{array}$ & $\begin{array}{l}2.57 \pm 1.19 \\
158+068\end{array}$ & $\begin{array}{l}0.63 \pm 0.52 \\
035+0.20\end{array}$ & $\begin{array}{l}<0.001 \\
<0001\end{array}$ \\
\hline P value** & & & 0.001 & \\
\hline $\begin{array}{l}\mathrm{BMI} \geq 25 \\
(\mathrm{~kg} / \mathrm{m} 2)\end{array}$ & $1.93 \pm 1.01$ & $2.53 \pm 1.26$ & $0.60 \pm 0.47$ & $<0.001$ \\
\hline $\begin{array}{l}\text { BMI <25 } \\
(\mathrm{kg} / \mathrm{m} 2)\end{array}$ & $1.33 \pm 0.57$ & $1.78 \pm 0.72$ & $0.45 \pm 0.46$ & $<0.001$ \\
\hline P value** & & & 0.168 & \\
\hline
\end{tabular}

The comparison of median, mean and percentage between the groups is demonstrated in table V.

Table V: Comparison of median, mean \& percentages of the increase in the internal jugular vein diameter and CSA with control using different methods. $(\mathrm{N}=\mathbf{8 0})$

\begin{tabular}{|l|l|l|l|l|l|l|}
\hline \multicolumn{2}{|l|}{ Maneuver } & Median & $\begin{array}{l}\text { 25th } \\
\text { percentile }\end{array}$ & $\begin{array}{l}75 \text { th } \\
\text { percentile }\end{array}$ & Mean \pm SD & $\begin{array}{l}\text { P } \\
\text { value* }\end{array}$ \\
\hline $\begin{array}{l}\text { Maximum } \\
\text { diameter }\end{array}$ & $\begin{array}{l}\text { Hepatic } \\
\text { compression } \\
\begin{array}{l}\text { Legs } \\
\text { elevation }\end{array}\end{array}$ & 36.61 & 14.47 & 55.95 & $40.21 \pm 29.61$ & $<$ \\
\hline CSA & $\begin{array}{l}\text { Hepatic } \\
\text { compression } \\
\text { Legs } \\
\text { elevation }\end{array}$ & 79.35 & 34.49 & 134.47 & $93.86 \pm 73.32$ & $<$ \\
\hline *Paired t test P value for the difference between hepatic compression and legs elevations \\
\hline \multicolumn{7}{|l|}{} \\
\hline
\end{tabular}

\section{Discussion}

This study dealt with middle aged patients with a mean age of $(37.75 \pm 12.16)$ years, that was nearly similar to the mean age of patients who were enrolled by Dhulkhed et $\mathrm{al}^{21}$ $(35.65 \pm 9.69)$ years with a nearly similar gender distribution. The mean age was less than the mean age of the three regional studies by Gok et a $1^{14}$ and Erkan et $\mathrm{al}^{22}$ in Turkey, and Masjedi et $\mathrm{al}^{18}$ in Iran who gave a mean age of $49.33 \pm 21$, $47.83 \pm 15.07$, and $50.5 \pm 00$ years respectively. The Korean studies of Kim et $\mathrm{al}^{15}$ and Seong et $\mathrm{al}^{23}$ dealt with 
patients who were younger with a mean age $27.6 \pm 1.9$ and $28.15 \pm 2.85$ years respectively, when they compared the diameter of the IJV during supine, PLE, and different $(\mathrm{T})$ maneuvers. The most famous study about the effect of different maneuvers on the IJV diameter and CSA was done on infants with a mean age of $5.8 \pm 2.9$ months by Verghese et al when they use Valsalva, liver compression, and different $(\mathrm{T})$ positions ${ }^{4}$.

The majority of the involved patients were in the overweight category. The result was similar to the mean BMI of patients who were enrolled by both Magnano et $\mathrm{al}^{24}$ and Gok et $\mathrm{al}^{14}$ which was in the same category around 26 $\mathrm{kg} / \mathrm{m}^{2}$. Other studies were done on patients with a lower BMI like Yoon et $\mathrm{al}^{25}$ and Tarnoki et $\mathrm{al}^{11}$, which was around $24 \mathrm{~kg} / \mathrm{m}^{2}$, and Judickas et $\mathrm{al}^{26}$ which was around $22 \mathrm{~kg} / \mathrm{m}^{2}$. Although there was a significant statistical relationship between the BMI of the patients and achieving the maximal CSA of the right IJV and diameter, its effect on choosing different maneuvers in different studies is minimal, because this study and the aforementioned studies were performed on normal and overweight adult patients, and it was not a restriction to any of the procedures done e $^{11,14,15,19,24-26}$.

The mean DBP, SBP, and MAP of the patients were in the normal ranges, in concordance with other regional studies by Karaaslan et $\mathrm{al}^{27}$ and Gok et $\mathrm{al}^{14}$.

Hepatic compression had achieved the maximal increase in both right IJV diameter and CSA when comparing the two parameters from that in the baseline measurements in the control group. There was statistically significant increase in the IJV diameter about $0.44 \pm 0.27 \mathrm{~cm}$, and the CSA of the right IJV which is about $0.93 \pm 0.59 \mathrm{~cm}^{2}$ from the baseline measurements during hepatic compression. The increase of CSA of the right IJV during hepatic compression was more than that achieved by Lobato et al which was statistically significant
$1.6 \pm 0.86 \mathrm{~cm}^{2}$ from the baseline supine position, to be $2.16 \pm 1.20 \mathrm{~cm}^{2}$, when they examine 15 adult patients undergoing central venous cannulation via the right IJV as part of their anesthetic plan compared to a control group ${ }^{17}$.

Verghese et al measured the effect of the combination of different maneuvers (Trendelenburg position, Valsalva maneuver, and hepatic compression) on the CSA of the right IJV in infants and young children, and achieved a significant increase of about 14\% from the baseline supine position measurements in young children, compared to only $7 \%$ in infants. They attributed this difference to the different collapsibility of the right IJV between the two age groups and to the study characteristics, in addition to the small size and short stature that attributed minimally to the venous return making it an inefficient way to increase the size of the IJV ${ }^{4}$.

There was more increase in the CSA of the IJV in this study than that of Verghese et al, because the CSA of the IJV enlarges with age, a phenomenon which is more pronounced in the right IJV than the left IJV, and in males more than females ${ }^{24}$.

The result of Bellazzini et al is in contradiction with this study, and the aforementioned two studies, as they concluded that hepatic pressure will not lead to a statistically significant increase in CSA of the IJV as compared with control $^{20}$.

Maneuvers designed to increase intravascular pressure tend to increase the CSA of the right IJV and, in turn, make the right IJV less prone to collapse when compressed $^{28}$. The elevation of the intravascular pressure will increase the chances of successful cannulation. Even though, the hepatic compression will not dilate the right IJV further, the progressive increase in intravascular pressure presumably makes the vessel less collapsible, thus may facilitate needle entry during right IJV cannulation ${ }^{17,29}$. 
Of note, the hepatojugular reflux is not commonly exaggerated in healthy subjects. Therefore, hepatic compression may be a reasonable maneuver to try in a patient with elevated right ventricular pressure $^{20}$.

The increase in the diameter of the right IJV and the CSA that which was achieved during the PLE in this study were less than the corresponding increase achieved by the hepatic compression; although it was significant statistically.

The passive legs elevation redistributes blood from the lower extremities into the central circulation. It is a relatively easy manoeuvre, and is used when the Valsalva manoeuvre, abdominal compression, or the Trendelenburg position may be not applicable or create discomfort to patients ${ }^{15}$.

Kim JT et al study achieved a significant increase in the CSA of the right IJV which is comparable to this study when using the PLE alone. They studied the effect of PLE in comparison to the Trendelenburg position, and found the latter to be more effective than the leg elevation in increasing the CSA in awake young adult patients who undergone IJV cannulation. They proposed that the PLE may be an alternative to the Trendelenburg position in patients who had some contraindication to the procedure $^{15}$.

$\mathrm{Gu}$ et $\mathrm{al}^{19}$ reported a similar result to the present study and that of Kim JT et al ${ }^{15}$ in young adult patients. They also evaluate the effect of different durations of the PLE on the diameter and found that the increase in the IJV diameter is achieved when PLE lasts one minute in comparison to a decrease in diameter after 10 minutes' leg elevation. Interestingly, PLE for $10 \mathrm{~min}$ reduced the distended jugular veins to an extent; because the hemodynamic effects of leg elevation would reach their maximum within one min and diminish rapidly thereafter ${ }^{30,31}$.

Kim WH et al study concluded that PLE was as effective as Trendelenburg position to increase the CSA of the IJV in infants and young children only ${ }^{5}$.

Generally, the hepatic compression, passive legs elevation, and other maneuvers have been recommended to increase the CSA of the IJV in adults $^{15,28,32}$. However, studies that have evaluated some of these maneuvers in infants or young children reported few clinically significant increases in the CSA, especially in infants ${ }^{4,5}$. Because IJV catheterization would be easier on a large $\mathrm{IJV}$, it is necessary for evaluating the maneuver to increase in the CSA of IJV in infants and small children. The PLE can be performed easily in infants or small children, avoids increase of intracranial pressure, and does not require a tilt table to place the head in the down position $^{5}$. Armstrong et al reported that PLE and abdominal compression achieved significant mean increase of the IJV diameter in healthy young adults (12.6 and $12.2 \mathrm{~mm}$ ) respectively from the baseline diameter which was $(11.5 \mathrm{~mm})$, with similar confidence intervals ${ }^{28}$.

In conclusion, the hepatic compression is significantly superior to the passive legs elevation in achieving more right IJV diameter and the CSA in the male, irrespective to age and BMI.

The main limitations of this study were: Two maneuvers only were used to increase the CSA of the right IJV.

No comparison to patients who had combination of any two maneuvers.

The study did not involve infants, neonatas, children, or adolescent age group to be compared the enrolled adult patients of 19-55 years age range.

The study recommends the following:

The use of hepatic compression as a procedure of effective right IJV cannulation whenever is applicable to achieve maximal IJV diameter and CSA for better access, especially in young adults. The use of passive leg elevation as an alternative procedure when the hepatic compression is contraindicated or not applicable. 


\section{Additional studies are needed to compare to other procedures to achieve maximal leg elevation and the hepatic compression benefits during the IJV cannulation.}

\section{References}

1.Denys BG, Uretsky BF, and Reddy PS. Ultrasound-assisted cannulation of the internal jugular vein, a prospective comparison to the external landmark-guided technique. Circulation May 1993; Vol 87 (5): 1557- 62.

2.Parmar S, Parikh S, and Mehtaet H. Anatomical variations of the internal jugular vein in relation to carotid artery: an ultrasound study. International Journal of Medical Science and Public Health 2013; Vol 2 (2): 223-8.

3.Brass P, Hellmich M, Kolodziej L, Schick G, Smith AF. Ultrasound guidance versus anatomical landmarks for internal jugular vein catheterization. Cochrane Database Syst Rev. 2015;1(1):CD006962. Published 2015 Jan 9. doi: 10.1002/14651858.CD006962.pub2

4.Verghese ST, Nath A, Zenger D, Patel RI, Kaplan RF, and Patel KM. The effects of the simulated Valsalva maneuver, liver compression, and/or Trendelenburg position on the cross-sectional area of the internal jugular vein in infants and young children. Anesth Analg 2002; 94:250-4.

5.Kim WH, Lee JH, Lee SM, Kim CS, Kang R, Yoo CS et al. The Effect of passive leg elevation and/or Trendelenburg position on the cross-sectional area of the internal jugular vein in infants and young children undergoing surgery for congenital heart disease. Anesth Analg 2013; 116:178-84.

6.Lin BS, Kong CW, Tarng DC, Huang TP, and Tang GJ. Anatomical variation of the internal jugular vein and its impact on temporary haemodialysis vascular access: an ultrasonographic survey in uraemic patients. Nephrol Dial Transplant (1998) 13: 1348.

7. Ortega R, Song M, Hansen CJ, and Barash P. Ultrasound-guided internal jugular vein cannulation. Engl J Med 2010; 362 : e57.

8.Solanki SL, Doctor JR, Kapila SJ, Jain A, Joshi M, Patil VP. Ultrasonographic assessment of internal jugular vein diameter and its relationship with the carotid artery at the apex, middle, and base of the triangle formed by two heads of sternocleidomastoid muscle: A pilot study in healthy volunteers. Saudi J Anaesth 2018; 12:578-83.

9.Lobato EB, Sulek CA, Moody RL, and Morey TE. Cross-sectional area of the right and left internal jugular veins. Journal of Cardiothoracic and Vascular Anesthesia April 1999; Vol 13(2): 136-8.

10.Ybarra LF, Ruiz H, Silva MP, Lederman HM, and Schettini ST. Ultrasound evaluations of internal jugular vein punction techniques in children: the easiest method to reach the target area. Pediatr Surg Int (2009) 25:99-104.

11.Tarnoki AD, Molnar AA, Tarnoki DL, Littvay L, Medda E, Fagnani C, et al. Heritability of the dimensions, compliance and distensibility of the human internal jugular vein wall. PLoS ONE 13(3): e0192948. https://doi.org/10.1371/journal.pone.0192948.

12.Bérczi V, Molnàr AA, Apor A, Kovács V, Ruzics C, Várallyay C, et al. Eur J Appl Physiol 2005; 95: 283-9.

13.Maheshwari P, Kelsheimer B, and Maheshwari P. Novel maneuvers to increase the internal jugular vein diameter during ultrasound-guided cannulation. Can J Anesth/J Can Anesth 2016; 63:898-900.

14.Gok F, Sarkilar G, Kilicaslan A, Yosunkaya A, Uzun ST. Comparison of the effect of the Trendelenburg and passive leg raising positions on internal jugular vein size in critically ill patients. Int J Clin Exp Med. 2015;8(10):19037-43.

15.Kim JT, Kim HS, Lim YJ, Bahk JH, Lee KH, Kim CS, et al. The influence of passive leg elevation on the cross-sectional area of the internal jugular vein and the subclavian vein in awake adults. Anaesth Intensive Care 2008; 36: 65-8.

16.Dincyurek GN, Mogol EB, Turker G, Yavascaoglu B, Gurbet A, Kaya FN, et al. The effects of the Trendelenburg position and the Valsalva manoeuvre on internal jugular vein diameter and placement in children. Singapore Med J 2015; 56(8): 468-71.

17.Lobato EB, Florete Jr. OG, Paige GB, and Morey TE. Cross-sectional area and intravascular pressure of the right internal jugular vein during anesthesia: effects of Trendelenburg position, positive intrathoracic pressure, and hepatic compression. Journal of Clinical Anesthesia 1998; 10: 1-5.

18.Masjedi M, Sasani MR, Riahialam M, Hadavi MR, Rakhshan M, and Bakhodaei HH. The effect of passive leg raising maneuver on right internal jugular vein dimension in ICU patients under mechanical ventilation. World Family Medicine 2018;16(2):300-6.

19.Gu YJ, Lee JH, and Seo JI. Effect of lumbar elevation on dilatation of the central veins in normal subjects, American Journal of Emergency Medicine 2018; https://doi.org/10.1016/j.ajem.2018.07.032.

20.Bellazzini MA, Rankin PM, Gangnon RE, and Bjoernsen LP. Ultrasound validation of maneuvers to increase internal jugular vein cross-sectional area and decrease compressibility. American Journal of Emergency Medicine 2009; 27: 454-9.

21.Dhulkhed V, Reddy A, Gupta A, and Dhulkhed P. An observational study of change in diameter of right internal jugular vein with various body positions in volunteers with the aid of 2-dimensional ultrasonography. The Internet Journal of Anesthesiology Volume 21 (2): 1-6.

22.Erkan SO, Tuhanioğlu B, Arslan M, Erkan Z, Küȩükoğlu T, Yildirim I. Assessment of internal jugular vein diameters in Turkish adults. Cumhuriyet Medical Journal June 2018, Volume 40(2): 142-9.

23. Seong H, Kang B, Kim G. Comparison of internal jugular vein dilation between Valsalva maneuver and proximal internal jugular vein compression. Clin Exp Emerg Med 2016;3(4):193-6.

24.Magnano C, Belov P, Krawiecki J, Hagemeier J, Beggs C, and Zivadinov R. Internal jugular vein cross-sectional area enlargement is associated with aging in healthy individuals. PLOS ONE 2016; 11(2): e0149532. doi: 10.1371/journal. pone.0149532.

25.Yoon HK, Lee HK, Jeon YT, Hwang JW, Lim SM, and Park HP. Clinical Significance of the Cross-Sectional Area of the Internal Jugular Vein. Journal of Cardiothoracic and Vascular Anesthesia August 2013; Vol 27(4): 685-9.

26.Judickas Š, Gineityte D, Kezyte G, Gaižauskas E, Šerpytis M, and Šipylaite J. Is the Trendelenburg position the only way to better visualize internal jugular veins? ACTA Medica Lituanica 2018; Vol 25(3): 125- 31.

27.Karaaslan P, Gokay BV, Karakaya MA, Darcin K, Karakaya AD, Ormeci T, et al. Comparison of the Trendelenburg position versus upper-limb tourniquet on internal jugular vein diameter. Ann Saudi Med 2017; 37(4): 308-12.

28.Armstrong PJ, Sutherland R, and Scott DHT. The effect of position and different manoeuvres on internal jugular vein diameter size. Acta Anaesthesiol Scand 1994: 38: 229-31.

29.Ewy GA. The abdominojugular test: technique and hemodynamic correlates. Annals of Internal Medicine. 1988; 109:456-60.

30.Monnet X, Rienzo M, Osman D, Anguel N, Richard C, Pinsky MR, et al. Passive leg raising predicts fluid responsiveness in the critically ill. Crit Care Med 2006; 34:1402-7.

31.Xavier Monnet X, and Teboul J. Passive leg raising. Intensive Care Med 2008; 34:659-63.

32.Mallory DL, Shawker T, Evans RG, McGee WT, Brenner M, Parker M, et al. Effects of clinical maneuvers on sonographically determined internal jugular vein size during venous cannulation. Crit Care Med. 1990 Nov; 18(11):1269-73. 